\title{
Exploring Human Resource Management System of Saudi Electricity Company: A Review of Policies for Effective Workforce Management
}

\author{
Alshahrani Ahmed Saeed A, Alqahtani Abdulaziz Mubark, Alshahrani Bander Sayaf Z \\ School of Management, Wuhan University of Technology, Wuhan, P.R. China \\ Dental department, Armed Forces Hospital, Sharurah city, Saudi Arabia \\ E-mail (corresponding author):sound.earth@hotmail.com
}

\begin{abstract}
In this paper, we investigate the current state of human resource management development by conducting a case study of Saudi Electricity Company. Through interviews with HR managers, documentation and archival records examination, we were able to describe and systemize HR policies designed to ensure the well-being of Saudi Electricity Company employees. The findings suggest that Saudi Electricity Company's level of HRM practice is of appropriate level, with comprehensive medical and social care being provided. Furthermore, the company recognizes good work performed by the employees and rewards them for their loyalty. Through the implementation of the performance management system, the company is able to evaluate the performance of the employees, monitor their progress and offer training and development programs. The value of the conducted case study is that other Saudi Arabian companies can learn and implement similar policies from a successful Saudi Arabian case, instead of blindly copying western management practices.
\end{abstract}

Key words: Saudi Electricity Company, HRM, Employee Well-Being, Saudi Arabia

\section{Introduction}

Poor working conditions, inadequate salaries and promotion (Allen and Katz, 1995), low employee well-being (Packendorff, 2002; Turner et al., 2008b), stress (Aitken and Crawford, 2007; Gallstedt, 2003), work overload (Zika-Viktorsson et al., 2006) and consequently employee dissatisfaction and high staff turnover are all surfacing problems that occur in the absence of quality HRM policy. As a result, organizations are unable to find and retain adequate talent, which is an obstacle for organizations' growth (Ready and Conger 2007). 
Additionally, sometimes lack of HRM policies has even a detrimental indirect impact on organizational outcomes. For instance, shortage of medical staff due to low retention rates and high turnover of hospital workers may lead to higher mortality rate among patients (Deshopande and Golhar, 1994). On the other hand, creation and effective implementation of HRM policies contributes to organizational performance (Becker and Huselid, 1998), competitive advantage (Delaney et al. 1996, Boselie et al. 2005, Florkowski and Schuler 1994) and enhanced morale and the productivity of organizations (Zeynep and Huckman 2008).

Through effective employee recruitment, health and social security system, training and development, performance appraisal and employee rewarding systems, organizations are able to cater to the needs of the workforce, which results in more satisfied employees and more effective job performance (Shipton et al., 2006). Designing and implementing quality HRM policies will establish and retain a qualified, well cooperating workforce and therefore, ultimately, result an increase of organizational growth, efficiency, and profitability.

Analysis of the human resource practices in Saudi Arabia organizations is an important, yet relatively neglected research area within the field of human resource management. Only few studies have examined company policies in the Arab gulf countries context. High dependency on oil industry, increasing foreign labor force, inappropriately designed education system and social values (Mellahi and Johnson, 2000; Achoui, 2009) contribute to a poor development of HRM in Saudi Arabia. When it comes to HRM practices in Saudi Arabia, there are huge opportunities for improvement and standardization. Recently Saudi government has put emphasis on developing HR sector. As a part of the initiative, a "Saudization Plan" aims at preparing Saudi employees to replace expatriates in accordance with the company's objectives. The plan includes identifying a target job for each employee, preparing individual development programs and on-the-job training programs. Plan also implies effective implementation of such programs. There are many valuable insights that can be attained by studying companies that put emphasis on HRM and take pride in their workforce and their wellbeing. Specific HRM problems in Saudi Arabia and other Islamic countries require further addressing. In other words, in order to identify the factors, which increase the efficiency of the techniques and policies, first, a clear definition and detailed exploration of existing policies in Saudi Arabian organizations need to be conducted. In this paper, we provide a detailed analysis of HRM policies in one of the leading companies in Saudi Arabia, Saudi Electricity Company. The study will enable us to see which policies are being used for efficient workforce management. This study also builds a foundation for future research that aims at explaining factors conducive to employees' well-being in the Saudi Arabian context. Following questions are going to be addressed: What policies are aimed to secure the well-being of the workers? Which specific policies are aimed at training and developing the workforce of Saudi Electricity Company? How the performance of employees is managed and evaluated?

With the aim of answering these questions, first, we provide an overview of the HRM process and its role in motivating employees. Next, we introduce the methodology applied in the study. In the fourth section, Saudi Electricity Company is introduced. We describe specific HRM policies encompassing medical care, social care, employee rewarding system, and performance management aimed at increasing the well-being of employees. Finally, implications of the study are discussed followed by the conclusion. 


\section{The value of HRM policies for employee motivation and}

\section{organization}

Intrinsic factors really do have an influence on employees, as indicated in human resource management research, which are based on meeting the personal needs of an individual (Zika-Viktorsson et al., 2006). Human beings have a number of key psychological needs including need to feel that one can do something well, need to be part of a group and finally, need for respect and encouragement from others. (MacDuffie, 1995). How people are managed within certain organizations, wit a strong focus on systems and policies, is a primary concern of human resource management. The departments and units in organizations are typically responsible for a number of activities. Effective companies have well developed HRM processes, such as recruiting, developing and appraising (Armstrong, 1992).

Day-to-day administration and decisions that can have a profound effect on the company's identity, performance and strategic direction are just some of the wide-ranging tasks of a human resources team (Price, 2011). In general, the human resource management spectrum is more mundane and everyday administrative tasks such as payroll processing wage issues and employee benefits, personnel recruitment and staff training (Chang, 1999). This is where the difference between an ordinary and a highly skilled human resource management team come into play, where the latter here is able to consider and contribute to the company's guiding vision in the process of planning and executing training schemes and recruitment drives, monitoring the workforce by means of regular performance appraisals and on-going review as well as maintaining a positive atmosphere in the workplace (Huselid, 1995). A highly skilled human resources expert will ensure that a company is able to keep a close eye on the progress and potential of its employees, by applying a wide range of tools and methods and by assembling their skills and strengths into the growth of the business (Wright et al., 1996).

In Saudi Electricity Company performance management system has been implemented, entailing planning, orienting, developing, enhancing and appraising the employee's job performance in order to ensure fulfilment of the company objectives. The comprehensive goal of this system is to establish a culture where managers, individuals and groups undertake the responsibility for ongoing development of company business and enhancement of their skills and capabilities so that company targets can be efficiently realized. More specifically, Saudi Electricity Company management aims at appraising employee's performance of current job, defining employee's development needs, defining procedures needed for job performance development, establishing a classification system that distinguishes levels of performance and establishing criteria for granting annual increments or promotions in line with company regulations.

Saudi Electric Company has a rich history and deep strives for human resource practice effectiveness. Care for its employees is even emphasized in the company mission as follows; "We are committed to provide our customers with safe and reliable electric services, meeting the expectations of our shareholders, caring about our employees, and ensuring optimum utilization of available resources." 
Therefore, in our effort to provide information on HRM policies within Saudi Arabia, we conduct a research in a company that takes pride in their employees. An effective HRM policy that fulfills company mission and contributes to its vision is what all companies should strive. A case study of Saudi Electricity Company HRM policies has been conducted in order to provide an insight into one of the most effective Saudi Arabian companies in terms of HR and organizational outcomes.

\section{Research methodology}

In order to address the research questions of the study and describe the situation in terms of HRM policies in Saudi Electricity Company, we applied a qualitative research with the main purpose to explore existing HRM policies and their implications for the company employees. A case study research strategy utilizing multiple sources of data in order to ensure reliability of the study has been applied (Robson, 2002). In the investigation process, we sourced data from archival records and documentation. We have examined the company policies and documents on the HR related issues in terms of the variables that we have identified in our study as relevant for effective HR practice. Documents from HR managers that explain and report important aspects of HR practice, encompassing health services offered to the employees, saving plan and rewards and performance management process have been widely used. We accessed data through relevant HR managers working for Saudi Electricity Company. In order to clearly communicate relevant aspects of the policies, we additionally conducted interviews with HR managers. Information on socially vulnerable groups, their health insurance coverage as well as their hospital treatments was described as a part of company health care services. Company reward system was defined in terms of certificates, recognition and rewards given to company employees. Specific elements of performance management system were also described.

\section{Review of Saudi Electricity Company and HRM policies}

Saudi Electricity Company (SEC) was established by Ministerial Resolution endorsed by the Royal Decree and announced by the decision of Minister of Commerce. It is one of the biggest and financially most successful electrical companies in Saudi Arabia. Part of its powerful position stems from competent workforce. The company is confident that its employees are able to take responsibility and perform jobs assigned to them well. Moreover, company always seeds to gain the trust of its employees by raising their morale, promoting better human relations and effective communications among the administrative and technical levels (Saudi Electricity Company). The company itself takes pride in its HR department and HR policies, which meet the legal requirements and help maintain company's competitive position (Gratton and Truss, 2003). By prevailing practices in the work market in the Kingdom of Saudi Arabia, the company is constantly working on establishing and improving HR policies, described as reliability, equity and competition. Such quality policy can attract, motivate and keep personnel in its service eventually enabling them to perform their functions efficiently. Some of the tasks and responsibilities of Human Resources incluedes preparation, review and 
implementation of employees' benefits policies, circulation of all benefit policies to company's departments and the response to any employee inquiry on time.

Through numerous training programs, the company also carries out training and addresses development needs of its employees, work assignments and functional rotations. The company is very eager to encourages employees to participate in seminars and world conferences so that they can expand their knowledge on current scientific topics through discussions and eventually bring benefit to the company and its business.

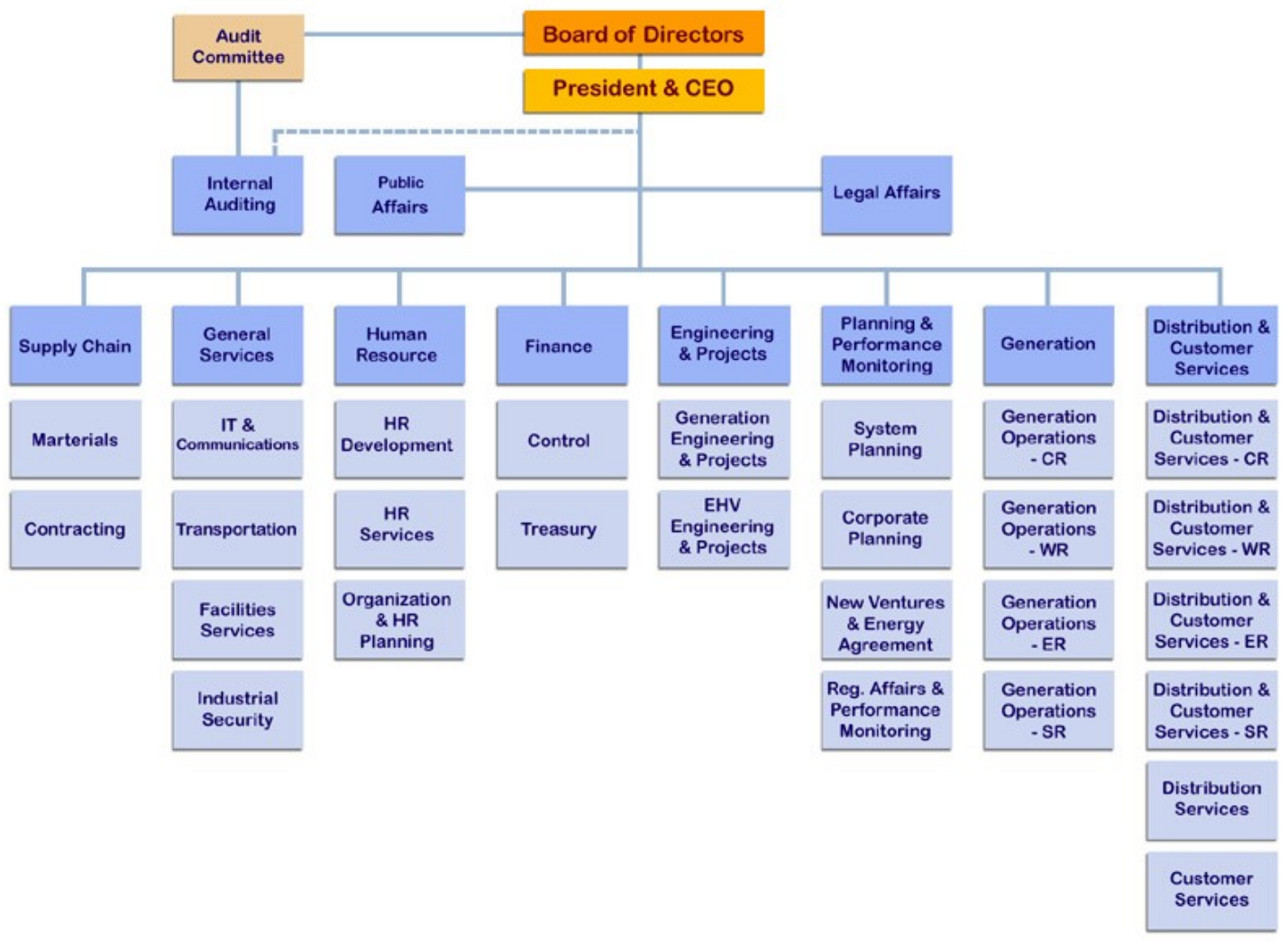

Figure 4-1 Saudi Electricity Company Organizational Chart

\subsection{Provision of health services}

As a part of its HRM policies, it is the company policy to provide competent medical care to its employees and eligible dependents. Medical care includes variety of outpatient clinic services and several hospitalization services (diagnostic services treatment, medicines, delivery and surgical operations) enlisted by the company's Health Care Policy. 


\begin{tabular}{|c|c|c|c|c|c|}
\hline Item & Employee & Wife/widow & SOS (Gregorian & Daughters & Parents \\
\hline Saudi employee & Covered & covered & $18^{* * *}$ & Marriage** & o/p clinics ${ }^{* *}$ \\
\hline Expatriate employee & Covered & covered & 18 & 18 & not covered \\
\hline Trainee-non-employee & (non-employee) & o/p clinics** & & & \\
\hline $\begin{array}{l}\text { Early retired Saudi employee } \\
\text { through the company until } \\
\text { he reaches age of normal } \\
\text { retirement }\end{array}$ & Covered & covered & $18^{* * *}$ & Marriage** & $\mathrm{o} / \mathrm{p}$ clinics ${ }^{* *}$ \\
\hline $\begin{array}{l}\text { Early retired Saudi employee } \\
\text { through the company until } \\
\text { he reaches age of normal } \\
\text { retirement (for five Gregorian } \\
\text { years }{ }^{* * *} \text { ) }\end{array}$ & o/p clinics ${ }^{* *}$ & o/p clinics** & not covered & not covered & not covered \\
\hline $\begin{array}{l}\text { Saudi employee normally } \\
\text { retired, (for five Gregorian } \\
\text { years }^{* * * *} \text { ) }\end{array}$ & o/p clinics** & $\mathrm{o} / \mathrm{p}$ clinics** & not covered & not covered & not covered \\
\hline $\begin{array}{l}\text { Saudi employee terminated } \\
\text { because of occupational } \\
\text { disablement, (for one } \\
\text { Gregorian year from date of } \\
\text { termination). }\end{array}$ & Covered & covered & 18 & Marriage* & o/p clinics ${ }^{* *}$ \\
\hline $\begin{array}{l}\text { Dependents of decedent } \\
\text { Saudi employee,(for one } \\
\text { Gregorian year from date of } \\
\text { death) }\end{array}$ & N/A & covered & 18 & Marriage* & o/p clinics ${ }^{* *}$ \\
\hline
\end{tabular}

Table 4-2 Eligibility to Medical Care 
Insurance policy of the company is quite comprehensive and aims at protecting socially vulnerable part of the employee and his/her family members. For instance, if Saudi employee's daughter becomes widow, she will be added as an eligible dependents for working father (her sons and daughters are not considered). Similarly, if a daughter of an employee got divorce, she will be added into the list of eligible dependents for her working father (her sons and daughters are not considered).

\begin{tabular}{|l|lll|}
\hline \multirow{2}{*}{ Employee's Grade } & \multicolumn{3}{|l|}{ Level of Hospitalization in Contracted Hospitals } \\
\cline { 2 - 4 } & Employee & Wife & Children \\
\hline 53 and above & Single room & Single room & Single room \\
\hline Remaining grades & Shared room & Shared room & Shared room \\
& & & \\
\hline Note: Single room with a maximum cost of (SR600) per night. \\
\hline
\end{tabular}

Table 4-3 Level of Hospitalization in Contracted Hospitals

\begin{tabular}{|c|c|c|c|c|}
\hline Item & Visit & Hospitalizatiol & & \\
\hline $\begin{array}{l}\text { Daily } \\
\text { allowance }\end{array}$ & Employee/ escort & Employee & Escort - abroad & \\
\hline 1 & $\begin{array}{l}\text { Living and transport (in } \\
\text { kingdom) }\end{array}$ & (SR150) daily & $\begin{array}{l}\text { (SR 100) only for } \\
\text { admission and } \\
\text { discharge days }\end{array}$ & $\begin{array}{l}\text { (SR1OO) } \\
\text { daily }\end{array}$ \\
\hline 2 & $\begin{array}{l}\text { Living and } \\
\text { transport(Arab and } \\
\text { Asian countries) }\end{array}$ & (SRIOO) daily & $\begin{array}{l}\text { (SR 50) only for } \\
\text { admission and } \\
\text { discharge days }\end{array}$ & (SR50) daily \\
\hline 3 & $\begin{array}{l}\text { Living and transport( } \\
\text { other countries) }\end{array}$ & (SRI 50) daily & $\begin{array}{l}\text { (SR 100) only for } \\
\text { admission and } \\
\text { discharge days }\end{array}$ & $\begin{array}{l}\text { (SR1OO) } \\
\text { daily }\end{array}$ \\
\hline
\end{tabular}

\section{Table 4-4 Compensation of Medical Costs}

In case of illness, hospitalization will be offered to the employees and the family members. In table, the level of hospitalization depending on the employee's grade is illustrated. Medical costs will be compensated for employees and their eligible dependents. During the hospitalization period, company either provides 
accommodation or pays its actual cost at a maximum of two hundred Saudi Riyals (SR200) per night for the employee and his/her eligible dependent.

Saudi Electricity Company reserves the right to provide, whenever necessary, some excluded services based on the actual costs to be incurred by employee. However, as a recipient of health care, an employee bears responsibilities as well. Every employee needs to report on his medical case to the company's clinic or to its designated medical facility. It is also required from him to undergo medical examination, abide by the medical advice of the attending physician, follow established procedural rules for medical treatment and utilize medical services company provides optimally.

\subsection{Saving and thrift plan}

The company Board of Directors approved "Saving and Thrift Plan" for the Saudi employees. Company allocates a contribution against the amounts paid monthly by each participating employee to help its employees save money. Employee's contribution may range between $1 \%$ and $10 \%$ of the basic salary. Company invests participants' savings in Islamic funds following principles and rules of Islamic investment and portfolios of low risks. Company allocates an amount equals to $100 \%$ of the participant's monthly contributions of his account. Participant's eligibility to company contributions will be calculated when the participation ends as follows:

\begin{tabular}{|l|l|}
\hline Years of continuous contribution & $\begin{array}{l}\text { Eligible percentage of company accumulated contribution } \\
\text { based on years of continuous contributions }\end{array}$ \\
\hline Upon completion of the 1st year & $10 \%$ \\
\hline Upon completion of the 2nd year & $20 \%$ \\
\hline Upon completion of the $3^{\text {rd }}$ & $30 \%$ \\
\hline Upon completion of the 4th year & $40 \%$ \\
\hline Upon completion of the 5 th year & $50 \%$ \\
\hline Upon completion of the 6th year & $60 \%$ \\
\hline Upon completion of the 7th year & $70 \%$ \\
\hline Upon completion of the 8th year & $80 \%$ \\
\hline Upon completion of the 9th year & $90 \%$ \\
\hline Upon completion of the 10 to 11 year or $100 \%$ \\
more
\end{tabular}

Table 4-5 Calculation of company contributions 


\subsection{Gifts, Certificates and Parties of Continuous Service}

The company recognizes the services of its employees upon completion of each five years of continuous service by issuing them appropriate service certificates. Employees who have completed five years of continuous service are presented certificates by their worksite supervisors. Employees who have completed ten to fifteen years of continuous service are presented certificates by their departments accompanied by a cake and tea party. Employees who have completed 20, 25, 30, 35, 40 years of continuous service are presented certificates and gifts in a dinner or lunch party. Gift value is added to monthly salary when employee completes years of service prescribed in the policy as follows:

\begin{tabular}{|l|l|l|l|l|l|l|l|}
\hline Years of service & 10 & 15 & 20 & 25 & 30 & 35 & 40 \\
\hline $\begin{array}{l}\text { Gift value for Dep. Managers and above in } \\
\text { Riyal }\end{array}$ & 1000 & 1500 & 2000 & 3000 & 4000 & 5000 & 6000 \\
\hline $\begin{array}{l}\text { Gift value for the rest of employees in } \\
\text { Riyal }\end{array}$ & 500 & 750 & 1000 & 1500 & 2000 & 2500 & 3000 \\
\hline
\end{tabular}

Table 4-6 Gifts values

Employees on grade (55) and above are treated as Department Managers with regard to value of Continuous Service Gift. Employees who have completed 25, 30, 35, 40 years of continuous service with the company are granted a paid leave as per company policy. In the case of normal and early retirement, the company recognizes the services of its employees by issuing them appropriate recognition certificates in a Lunch or Dinner party to be held in their honor.

\begin{tabular}{|l|l|}
\hline Years of Experience & Signature Authority \\
\hline 10 years or less & Employee's Department Manager \\
\hline More than 10 years and up to 30 & Employee's Sect or ED \\
\hline More than 30 years & Employee's EVP/SVP Business Unit \\
\hline
\end{tabular}

Table 4-7 Signature of Authority in Retirement

Competent employees related to customers' meter reading, testing and maintenance are eligible to an award as follows: When customer violations are detected by an employee, an award amount equals to $50 \%$ of the violation fine collected from the concerned customer is paid to this employee. Such violation should be included within the company's accredited list of violations as per the approved policy. The award will be paid after collecting the fine from the customer and entering it in company records. Such award(s) will be 


\section{Alshahrani Ahmed Saeed A, Alqahtani Abdulaziz Mubark, Alshahrani Bander Sayaf Z \\ Exploring Human Resource Management System of Saudi Electricity Company: A Review of Policies for Effective Workforce Management}

distributed equally among employees when the violation is detected by more than one employee or more than one employee is asked to confirm the violation or more than one employee is asked to contact the customer and collect the appropriate fine from him/her.

Employees whose services are terminated from the company will be eligible for a Service Termination Award in accordance with articles number 84, 85 and 87 of the Saudi Labor Law, taking into account exceptions stated in articles number 80 and 81 of the same law. An employee who is inflicted with an occupational disablement (partial or total) will be compensated in accordance with standard regulation.

\subsection{Performance Management in Saudi Electricity Company}

The performance management system was implemented in Saudi Electricity Company in January 2004. This new system consists of four elements: performance planning, performance orientation, performance appraisal and results enhancement. Performance Management of Saudi Electricity Company is a continuous process in which employees and supervisors constantly interact. It encompasses four different stages: performance planning, follow-up and performance guidance, review and performance assessment, and reinforcement. In the Performance Planning stage, a meeting is held between the employee and the supervisor at the beginning of each year to clarify objectives and the targets for all business units, sectors and departments within the company and to define the job's most important targets and performance criteria for the following year.

Given that performance management is an ongoing process, in the follow-up and Performance Guidance stage, employee and his supervisor should pay proper attention to performance development all over the year through: Performance control, Feedback Guidance and Support. Implementation of the employee's personal development plan during the year should be in line with his job route line and its current and future requirements.

Finally comes Review and Performance Assessment encompasses the discussion and review of performance against the agreed objectives during an official meeting between supervisor and the employee in the beginning of the year. The annual assessment is performed by supervisor, employee himself and colleagues. The comparison of performance to set objectives, standards and required competencies together with the planning and improvement and evaluating development needs is performed. In order to successfully implement Performance Management Program, reinforcement is done through promotions and annual increment plan, top Management compliments of distinguished achievements, link-to-job Route Planning and replacement schedules.

\subsubsection{Performance management mechanism review of skills and competencies}

The performance management program will be applied as follows: direct supervisor reviews the employee skills and competencies in accordance with the notes laid down during the appraisal period of the past year. Supervisors may learn more about competencies by consulting the company's appropriate manual. The most important competencies, which are reviewed in this appraisal, encompass experience, achievement, initiatives, customer service, trouble shooting, and commitment, working with others, flexibility, safety, 
Alshahrani Ahmed Saeed A, Alqahtani Abdulaziz Mubark, Alshahrani Bander Sayaf Z

Exploring Human Resource Management System of Saudi Electricity Company: A Review of Policies for Effective Workforce Management

confidence, influencing others and planning. Skills and competencies stated above are appraised and reviewed in line with this given levels: significantly exceeds expectations; exceeds expectations; meets all expectations; meets minimum expectations, does not meet expectations. General rating for performance level depends on the review of skills and competencies, along with the employee's performance. Normal distribution of performance rates in a Business Unit is as follows:

\begin{tabular}{|l|l|}
\hline Significantly exceeds expectations & $15 \%$ \\
\hline Exceeds expectations & $20 \%$ \\
\hline Meets all expectations & $60 \%$ \\
\hline Meets minimum expectations & $5 \%$ \\
\hline Does not meet expectations & \\
\hline
\end{tabular}

Table 4-8 Performance rates in a business unit

As a part of the employee performance review, direct supervisor reviews his subordinates' performance during the year, defining their contributions, achievements and obstacles. He also defines the employee's skills development during the last year and the needs for improvement next year. Direct supervisor is responsible for deciding the employee's overall appraisal, which should cover the whole appraisal period.

Once the appraisal report is signed by supervisor and also presented to the employee and singed by him, it should be submitted to the higher authority for review and approval.

\subsubsection{Performance planning}

Performance planning for the employee is a significant part of the performance management. Through discussion with the employee, direct supervisor define the job's most important targets for the coming twelve months. Targets, assessment criteria and duration are defined to realize specific goals. Also, current year achievements are defined. Then both parties sign defined objectives which is also approved by the higher authority. Furthermore, a performance development program is implemented as the supervisor and employee agree on the personal development plan for the coming twelve months by defining the required skills/competencies in relation to his/her job objectives now and in the future. Naturally, criteria for target achievement measurement, along with development plans and training programs which the employee is planned to attend, is specified. Notes should be taken, and the development plan should be signed by the employee and his direct supervisor and approved by the higher authority. In the supervisor-employee interaction, both parties have responsibilities which they need to exercise. For instance, direct supervisor undertakes employee performance appraisal whereas supervisory staff assume the duties of effective application of the performance management program in respect of their subordinates.

Employees are required to follow up their performance and always compare it to job standards and objectives agreed upon with supervisor at the beginning of the year. Additionally, they have to apply the development plan agreed upon with the direct supervisor, seek his/her guidance and orientation whenever 
needed, arrange to take corrective actions when needed in line with direct supervisor directions and propose whatever thought to develop work performance.

Finally, once the employee's performance appraisal is completed by his/her immediate supervisor, higher managerial authority (not lower than Division Manager) reviews employee's performance planning, development and appraisal. His/her responsibility is applied throughout the organizational units.

\subsubsection{Employee development}

The company provides training for its employees in order to achieve maximum productivity and to enhance the development and qualifications of Saudi personnel in line with the company's "Saudization" objectives. Consequently, the company's management assists Saudi employees to improve their skills and to develop their technical and professional abilities to the maximum of their potential. The company has established training and development programs to achieve these objectives, consistent with its manpower requirements. The programs include preparing prospective employees through management, professional, technical and administrative development programs. The company also ensures on-going career development and succession planning for qualified employees; help them improve their knowledge and skills and build capability to assume higher responsibilities. The company's training and development programs are essentially intended for Saudi nationals. In special cases, determined by management on a case by case basis, non-national employees may also be trained to meet specifically identified work requirements.

\subsubsection{Career development planning}

Career development is a series of interdependent activities and an important aspect of the integrated HR system that allows management to ensure a continued supply of well-trained employees who are current with the industry trends and technological developments needed for the efficient operation and development of the organization. It also means to enable availability of qualified employees in management and professional jobs on a continuing basis with a use of the performance management process. Regional Professional and Managerial Development Department along with the manager/supervisor reviews the development program that is drawn up and put into effect to determine the success level of such program(s) for potential use in future instances. Development Programs should be tailored to meet specific individual needs and always geared towards meeting the company's business and growth objectives. Succession planning is a critical tool in the career and management development of employees in the company. Managerial and Professional Development Department in coordination with the competent departments at the various sectors and business units oversee and implement the succession plans.

\subsection{Reimbursement of Expenses and termination of contract}

The company reimburses employees for authorized expenses incurred by them while carrying out company business, as per its approved regulations.

It is the company's policy to establish and maintain a favorable climate to the development of harmonious and effective relationships between the company and its employees, and amongst employees themselves at all levels. Towards this end, company tries to establish a sound system of communications between itself and 
its employees to promote good understanding of its objectives, policies and procedures by employees. To assist in the implementation of this policy, company has established procedures for handling disciplinary infractions through corrective guidance and dealing with employee grievances. The company endeavors to establish and maintain stability in employment keeping consistence with its requirements for efficient and economic operations. It is recognized, however, that a number of employees leave the company's service for various reasons. In case of termination, company carefully considers the circumstances of each case and ensures full compliance with the provisions of the applicable company policies, procedures, employment agreements, company's Organizational Chart and Table of Violations and Penalties as well as Saudi Labor Regulations.

\section{Discussion and implications}

The results of the study indicate that the level of HR in Saudi Electricity Company is of appropriate level. HRM policies addressing employees' needs and ensuring their well-being are in place. Policies define and encompass various aspects of medical services for employees, their saving plans, reward system as well as the tools created to evaluate, manage and improve Saudi Electricity Company performance.

As a part of the medical services, in most instances, employees and their dependents are eligible for wide range of services including hospitalization, covered expenses and sometimes even a care taker. Saudi Electricity Company with its policy often protects the socially vulnerable groups which have endured a period of personal and social instability.

The company is also involved in the savings plans of the employees ensuring that, after retirement, employees have a secure live. At the same time, during the employment period, the company makes effort to recognize the value of employees' work by giving out rewards, gifts and certificates, thus, creating an environment which values the workers and helps to create a favorable organizational culture. The company also has a well-defined and well-built performance management system in which all relevant stakeholder work like partners for the common benefit and prosperity of the organization. Supervisor and employee partnership is evident in almost any stage of the performance management process. This may help create a strong bond between supervisor and employee, consequently, having positive influence on employee job satisfaction given that leadership and positive attitude towards supervisor have positive influence on job satisfaction and performance (Cooke, 1990). If leader is perceived to exhibit consultative or participative leadership behavior, employees tend to be more satisfied with their jobs, with higher levels of organizational commitment as well as work performance (Yousef, 2000).The direct treatment by their managers and the extent to which they were informed about decisions and changes have a strong link with job satisfaction (McAuliffe et al., 2009). The supervisory support reflects a climate of trust, helpfulness, and friendliness between the supervisors and the subordinates (Hee Yoon et al., 2004).

Furthermore The Training and Managerial and Professional Development Departments are responsible for coordinating the implementation of the "Saudization Plan" in consultation with the concerned departments. 
In order for the company to reach the plans of the "Saudization" and to promote Saudi Arabian high skilled workforce training and development, future emphasis should be put on enhancing those programs that will help reach the specific targets of the company.

The study has implications both for theory and practice. Valuable insight into HRM policy of a Saudi Arabian company has been provided and knowledge on HR development levels in Saudi Arabia has been enriched. Given that Saudi Electricity Company is progressive in a sense of HR development; other companies may use this case study as a reference for developing their own HRM policies. More specifically, companies should work on creating and successfully implementing medical care and social plans for their employees. Furthermore, a well-planned recognition system to motivate the employees and to boost organizational culture where good work and loyalty is rewarded should be created. Finally, companies should make more effort to measure the effectiveness of their employees and work on the improvement of the human resources which in turn will also benefit the company.

\section{Conclusion}

The case study undertaken was aimed to explore the HRM policies and thus, answer questions on the extent of HRM development in one of the leading companies in Saudi Arabia. The study identified the policies applied to manage the workforce of the company which were designed to enhance the well-being of the workers and their relatives. Employee Social security and employee performance management are two principal parts that Saudi Electricity Company put emphasis in its operations. Medical care, pension and savings plans are taken care of by the company, and evaluation of employees is performed with trainings provided for their improvement. These are the social policies which are taken for granted in the western culture, with companies offering vast services for their employees. However, in the Saudi Arabian case where the HRM is at the state of development, a large number of companies do not have a clear standard and policies ensuring employees' well-being. In this, however, lies the biggest contribution of our study. By clearly identifying the policies of a company that has a developed HRM, others can use their case as a reference point to create their system of managing human resources.

The study still suffers from certain limitations. The policy coverage and analysis have not been comprehensive. It focused only on the social plan and performance management aspects of HRM. Given that HRM in Saudi Electricity Company is a comprehensive field, other aspects of organization and planning should also be examined. We have not evaluated the quality of certain processes and policies or the level of practical implementation. Therefore, future studies should exert effort to quantify the effectiveness of existing policies and determining which factors, in particular, have the highest contribution toward employee well-being in the context of Saudi Arabia. A quantitative analysis is therefore recommended. Future studies would help create a foundation for development of most effective HRM policies that will eventually take Saudi Arabia HR development closer towards fulfilling its role as a care taker of the companies' workers. 


\section{References}

- Aitken, A., \& Crawford, L. (2007). Coping with stress: Dispositional coping strategies of project managers. International Journal of Project Management, 25(7), 666-673.

- Achoui, M. M. (2009). Human resource development in Gulf countries: an analysis of the trends and challenges facing Saudi Arabia. Human Resource Development International, 12(1), 35-46.

- Allen, T. J., \& Katz, R. (1995). The project - oriented engineer: a dilemma for human resource management. R\&D Management, 25(2), 129-140.

- Armstrong, M. (1992). Human resource management. Strategy and Action, London.

- Becker, B. E., Huselid, M. A., Becker, B. E., \& Huselid, M. A. (1998). High performance work systems and firm performance: A synthesis of research and managerial implications. In Research in personnel and human resource management.

- Chang, W. L. (1999). Human resource management. Taipei, Taiwan: Hw-Tei (Chinese).

- Cooke, W. N. (1990). Factors influencing the effect of joint union-management programs on employee-supervisor relations. Industrial \& Labor Relations Review, 43(5), 587-603.

- Delaney, J. T., \& Huselid, M. A. (1996). The impact of human resource management practices on perceptions of organizational performance. Academy of Management journal, 39(4), 949-969.

- Deshopande, S. P., \& Golhar, D. Y. (1994). HRM practices in large and small manufacturing firms: A comparative study. Journal of Small Business Management, 32(2), 49.

- Florkowski, G. W., \& Schuler, R. S. (1994). Auditing human resource management in the global environment. International Journal of Human Resource Management, 5(4), 827-851.

- Gällstedt, M. (2003). Working conditions in projects: perceptions of stress and motivation among project team members and project managers. International Journal of Project Management, 21(6), 449-455.

- Gratton, L., \& Truss, C. (2003). The three-dimensional people strategy: Putting human resources policies into action. The Academy of Management Executive, 17(3), 74-86.

- Hee Yoon, M., Hyun Seo, J., \& Seog Yoon, T. (2004). Effects of contact employee supports on critical employee responses and customer service evaluation. Journal of Services Marketing, 18(5), 395-412.

- Huselid, M. A. (1995). The impact of human resource management practices on turnover, productivity, and corporate financial performance. Academy of management journal, 38(3), 635-672.

- MacDuffie, J. P. (1995). Human resource bundles and manufacturing performance: Organizational logic and flexible production systems in the world auto industry. Industrial and labor relations review, 48(2), 197-221.

- McAuliffe, E., Bowie, C., Manafa, O., Maseko, F., MacLachlan, M., Hevey, D., ... \& Chirwa, M. (2009). Measuring and managing the work environment of the mid-level provider-the neglected human resource. Hum Resour Health, 7, 13.

- Mellahi, K., \& Johnson, M. (2000). Does it pay to be a first mover in e. commerce? The case of Amazon. com. Management Decision, 38(7), 445-452. 
- Packendorff, J. (2002). The temporary society and its enemies: Projects from an individual perspective. Beyond Project Management: New Perspective on the Temporary-Permanent Delimma, Copenhagen Business School Press, Copenhagen, 39-58.

- Paauwe, J., \& Boselie, P. (2005). HRM and performance: what next?. Human Resource Management Journal, 15(4), 68-83.

- Price, A. (2011). Human resource management. Cengage Learning.

- Saudi Electricity Company, Retrieved from URL: https://www.se.com.sa/en-us/Pages/home.aspx

- Shipton, H., West, M. A., Dawson, J., Birdi, K., \& Patterson, M. (2006). HRM as a predictor of innovation. Human Resource Management Journal, 16(1), 3-27.

- Ton, Z., \& Huckman, R. S. (2008). Managing the impact of employee turnover on performance: The role of process conformance. Organization Science, 19(1), 56-68.

- Turner Parish, J., Cadwallader, S., \& Busch, P. (2008). Want to, need to, ought to: employee commitment to organizational change. Journal of Organizational Change Management, 21(1), 32-52.

- Wright, C., Mondy, R. W., and Noe, R. M. (1996). Human resource management.

- Yousef, D. A. (2002). Job satisfaction as a mediator of the relationship between role stressors and organizational commitment: A study from an Arabic cultural perspective. Journal of Managerial Psychology, 17(4), 250-266.

- Zika-Viktorsson, A., Sundström, P., \& Engwall, M. (2006). Project overload: An exploratory study of work and management in multi-project settings. International Journal of Project Management, 24(5), 385-394. 